dreadful spectres of all history, is at last yielding to science, and the most fruitful cause of war in the past is thus being eliminated. Instead we are now oppressed with the novel problems of plenty, the solution of which will in due course mean not only the passing of war, but of grinding poverty and slavish toil for the masses of mankind. In these and other ways the scientific results of the last twenty years will come in the future vastly to overshadow in importance the losses and dislocations of the Great War which still bulk so large in our view." General Smuts believes that scientific invention will make war more and more impossible. There is a more serious problem even than the risk of war, and that is the maintenance of liberty. It is the decay of principles that must be feared, and the disappearance of intellectual freedom. Every sincere thinker and every scientific investigator must welcome the challenge of this rectorial address. We must seek, with John Milton, to preserve "the high hopes and aims, the diligent alacrity of our extended thoughts and reasonings in the pursuance of truth and freedom".

\section{Memorial to Carl Daniel Ekman}

AN interesting ceremony was performed on behalf of the Swedish Cellulose Association by Consul T. Lundgren on October 19, when he unveiled a memorial to Carl Daniel Ekman, the inventor of the sulphite wood-pulp process, at Northfleet Cemetery. In the addresses by Baron Palmstierna and others at the dinner afterwards given by the Swedish Chamber of Commerce in London and the Society of Swedish Engineers in Great Britain, great emphasis was laid on the strengthening of Anglo-Swedish relations by mutual exchange of experience in science and technology. Sweden owes much to the many English pioneers who settled in Gothenburg during the last century and organised railways, exploited iron ore deposits and developed industrial life generally in the west of Sweden, but the debt has, however, been amply repaid by the work in England of many Swedes. The current issue of the Yearbook of the Society of Swedish Engineers deals with the work of some of these, such as Alfred Nobel, John Ericsson (1803-89) the inventor of the marine propeller and the first steam fire-engine, Nordenfelt (1843-1920) the gun and submarine designer, Sandberg (18321913) of steel-rail fame, and Ekman (1847-1904).

In 1870, attempts were being made to improve Mey's steam-cooking process for the conversion of wood into pulp for the manufacture of paper by adding soda to the liquor, but even then the product was not entirely satisfactory; it was not until 1872 that Ekman at Bergvik found that a solution contain. ing sulphurous acid and magnesite was the key to the problem. He thus laid the foundation of the sulphite process, the present world-production of which $(6,130,000$ tons a year) exceeds that of the sulphate or mechanical process in quantity as well as in value; further, the consequent cheapening of paper has brought the pleasures of reading into many homes. In 1883, Ekman became manager of a mill at North- fleet, Kent, and it was in his well-equipped laboratories there that much of his work on digesters and beaters and on the utilisation of the waste liquors was carried out. Ekman was the traditional type of inventor, and economics had no place in his enthusiasm for his technical work. As a result he died a poor man, and since the subscriptions to his memorial fund were devoted to the Ekman family and to the founding of scholarships, his grave became neglected. The memorial at Northfleet Cemetery is a result of the attention directed to this fact by Mr. J. Strachan, of the present Northfleet Mills.

\section{England-Australia Air Race}

Mr. C. W. A. Scorts and Mr. T. Campbell Black arrived at Melbourne at 5.35 a.m. (G.M.T.), on Tuesday, October 23, thus winning the EnglandAustralia air race. The flyers left Mildenhall, England, at 6.35 a.m. on Saturday, October 20, thus completing the journey, a distance of 11,300 miles, in 2 days 23 hours. The aeroplane was a new D.H. Comet, constructed at the de Havilland works specially for the race. It was a low-wing monoplane with two unsupercharged Gipsy Six engines (230 horse-power). Mr. C. W. A. Scott has already several notable flights to his credit. In 1931, he flew from England to Australia in 9 days 4 hours 11 minutes, in 1932 he did the same journey in 8 days 20 hours 44 minutes, and in 1931 he flew from Australia to England in 10 days 23 hours. Mr. Campbell Black set up a new world Puss-Moth record in 1931 by covering 1,600 miles in a single day. The second arrivals at Melbourne were Mr. Parmentier and Mr. Moll, flying a Dutch K.L.M. (Douglas) air liner carrying three passengers, who reached Melbourne at 12.54 a.m. (G.M.T.) on October 23, thus having completed the flight in just over three days. The flights are noteworthy achievements, for which tribute is due to the pilots for their skill and endurance, and not less to the designers and makers of the engines.

\section{Memorial to Capt. Cook}

ON October 15, during the Victorian centenary celebrations at Melbourne, the cottage from Great Ayton, North Riding of Yorkshire, associated with Capt. Cook, which was purchased by Mr. W. R. Grimwade, taken to Australia and re-erected in. Fitzroy Gardens, was formally handed over to the care of the Melbourne City Council. On the same day, at Great Ayton, Mrs. R. Linton, wife of the Agent-General for Victoria, unveiled a memorial which has been erected on the site once occupied by the cottage. The memorial consists of an obelisk of granite blocks brought from Cape Everard near Point Hicks, Australia, and is a facsimile of the obelisk at that spot, which states that Cook "First sighted Australia near this point which he named 'Point Hicks' after Lieutenant Zackary Hicks who first saw the land, April 19th (Ship's Log date), April 20th (Calendar date) 1770". In reply to a vote of thanks to Mrs. Linton and himself, the Hon. Richard Linton said: "We stand to-day beside a granite monument. It is a piece broken off from that 
continent whose discovery by Cook began the process of events that gave Britain one of the most faithful and loving of her daughters. It has been sent you in exchange. We have taken from you the home in which Cook's father and mother lived, which this day is being opened in Melbourne in one of the loveliest of our gardens. Beautiful English trees overhang it, green English lawns surround it, and glowing flowers form its setting." In the course of his speech Mr. Linton said: "Such men as James Cook are beacons. In our schools it should be our care that men like this should be held up to our children to follow, quite as much as those great warriors whose ultimate building lay through destruction rather than in construction."

\section{The Linnean Society of London}

The annual dinner of the Linnean Society of London was held at the Hotel Washington on October 18. The president, Dr. W. T. Calman, was in the chair, and the official guests were Sir Richard and Lady Gregory, and Dr. G. F. Herbert Smith. Following the dinner, a reception was held by the president and Mrs. Calman in the rooms of the Society at Burlington House. Dr. J. F. G. Wheeler, director of the Bermuda Marine Biological Station, gave a lecture, illustrated with coloured lantern slides, on the natural history of Bermuda. A number of zoological and botanical exhibits were shown in the library, including a series of manuscripts and printed documents, from the Society's archives, relating to the younger Linnæus, and to his visit to England in 1781-82. The Botanical Department of the British Museum (Natural History) had on view a large series of coloured drawings of fungi of the genus Russula, and a selection of dried plants from British Columbia. Miss F. L. Stephens exhibited cultures and microscopical preparations of two species of the fungal genus Neurospora showing varying degrees of the 'sub-sexual' difference known as heterothallism. A selection of coloured fruits and seeds exhibited by the Royal Botanical Gardens, Kew, attracted much attention. Prof. G. D. HaleCarpenter showed a series of butterflies with marks on, and mutilations of, the wings caused by the attacks of birds. Capt. J. G. Dollman exhibited a series of skins of certain antelopes showing the uniformity of pattern in the fotal and young animals, with diversity in the adults. Mr. J. Omer-Cooper had on view a living specimen of the crustacean Apus, hatched from mud taken from a pond in the New Forest. This crustacean had not been found in England for about half a century.

\section{Rainfall Records and Drought Periodicity}

Mr. W. R. BALDWIN-WisemaN, lecturer in hydraulics in the University of Western Australia, writing in reference to our leading article of August 4 on the "Government and Inland Water Survey", emphasises the need for an organised hydrographic service, and instances the Hydrographic Survey of the Po as one of the most efficient services in the world. From analyses of many lengthy records of rainfall in his possession, he contends that there is little justification in many cases, and no justification in some, for the assumption that any 35-year-mean approximates fairly closely to the true mean, or that a 20 per cent deficiency adequately represents the average annual deficiency of the three driest years in a lengthy rainfall record. Consequently, water works planned on these assumptions may make a too generous allocation of compensation water, while making inadequate provision for a storage sufficient to tide over the contingencies arising from a prolonged, or frequently recurrent, drought. $\mathrm{He}$ goes on to point out that Dr. E. Huntington has demonstrated the existence of a climatic pulse of about 640 years, which is probably a multiple of the sunspot period of 11.2 years $(57 \times 11 \cdot 2=638.4)$; if A.D. 1372, the year of maximum sunspot activity in the Chinese record, which has now been unofficially maintained for nearly a thousand years, be taken as a nodal point in this pulse, previous points will have occurred about 543 B.C., A.D. 95, and A.D. 734 all four points being in periods of notorious aridity. If the sequence is maintained, the next occurrence may be expected about A.D. 2010, with a prevalence of drought conditions, either prolonged or frequently recurrent, towards the elose of the present century.

\section{The North-East Coast Institution}

Ar the annual general meeting of the North-East Coast Institution of Engineers and Shipbuilders held at Newcastle-upon-Tyne on October 19, the report for 1933-34 was submitted, and Mr. J. T. Batey delivered his presidential address. In spite of the severe depression in the shipbuilding industries, the membership of the Institution has been well maintained, several valuable papers have been read and attendance at meetings during the past year was the highest recorded. Among other matters referred to were the grant of armorial bearings, the Sir Charles Parsons Memorial and the opening on July 20, 1933, of the Municipal Museum of Science and Industry, the formation of which the Institution did much to promote. The honorary curator of the Museum is Capt. E. W. Swan, a member of the Institution. A part of Mr. Batey's address was devoted to the problem of using technical progress. Technical progress, he said, is like a fine machine; it has to be properly used or it may be dangerous. Mechanical science has outstripped progress in the science of living, and it is evident that in this field there will be many and startling developments before the Institution is a century old. To the question whether the suspension of scientific progress is conceivable, it might be replied that the advance of science is so inevitable that for all practical purposes we may regard it as one of the laws of life. The Institution's purpose, "the advancement of the sciences of engineering and shipbuilding", is a definite function of the organised form of society ruling to-day. The responsibility for the misuse or oversight of technical progress must be accepted by finance, commerce and the State, internationally. In the session just opening, the Institution, he said, would commemorate its jubilee, and he continued : 